\title{
Evaluation of Chromite Recovery from Shaking Table Tailings by Magnetic Separation Method
}

\author{
Shayan Khakmardan ${ }^{1,2^{*}}$, Ramona Javadi Doodran ${ }^{1,2}$, Adel Shirazy ${ }^{3}$, Aref Shirazi ${ }^{1}$ \\ Ezatollah Mozaffari²
}

\author{
${ }^{1}$ Amirkabir University of Technology, Tehran, Iran \\ ${ }^{2}$ Imam Khomeini International University, Qazvin, Iran \\ ${ }^{3}$ Shahrood University of Technology, Shahrood, Semnan Province, Iran \\ Email: *skhmardan@aut.ac.ir, e.mozaffari@eng.ikiu.ac.ir
}

How to cite this paper: Khakmardan, S., Doodran, R.J., Shirazy, A., Shirazi, A. and Mozaffari, E. (2020) Evaluation of Chromite Recovery from Shaking Table Tailings by Magnetic Separation Method. Open Journal of Geology, 10, 1153-1163. https://doi.org/10.4236/ojg.2020.1012055

Received: November 12, 2020

Accepted: December 7, 2020

Published: December 10, 2020

Copyright $\odot 2020$ by author(s) and Scientific Research Publishing Inc. This work is licensed under the Creative Commons Attribution-NonCommercial International License (CC BY-NC 4.0) http://creativecommons.org/licenses/by-nc/4.0/

c) (1) () Open Access

\begin{abstract}
This study aimed to evaluate the chromite recovery from shaking table tailings of Forumad plant by a dry high-intensity magnetic separation. The average feed grade of chromium trioxide $\left(\mathrm{Cr}_{2} \mathrm{O}_{3}\right)$ was $7.62 \%$ by XRF. Also, different mineral phases were determined by $\mathrm{XRD}$, identifying the presence of Chrysotile, Augite, Albite, Chlorite and Chromite. Although the Forumad plant usually applies gravity methods utilizing the specific gravity difference between chromite and other gangue minerals, this study applied magnetic separation utilizing the paramagnetic nature of chromite crystals to recover chromite from tailings. 27 tests for 3 factors in 3 levels designed by the Taguchi method with design expert 12 software to determine the optimum conditions for the grade and recovery. Finally, the best condition was identified at 10,000 gauss (or 1 tesla) in the magnetic field intensity, $1 \mathrm{~kg} / \mathrm{min}$ feeding rate, and $40 \mathrm{rpm}$ drum rotating speed which produced a concentrate with $34.65 \%$ $\mathrm{Cr}_{2} \mathrm{O}_{3}$ and $59.42 \%$ recovery.
\end{abstract}

\section{Keywords}

Chromite, Magnetic Separation, Paramagnetic, Tailing Recovery

\section{Introduction}

Chromite is the major commercial source of chromium metal; this mineral is a part of the spinel group and usually occurs in ultrabasic rocks. It is a strategic mineral due to its high demand in the ferrochrome production industry and consequently stainless steel and other metallurgical alloys production [1]. There are various methods for exploring minerals and potential areas, including remote sensing and satellite image analysis [2] [3], also data processing by geosta- 
tistical methods [4] [5] [6] geochemical behavior study of elements [7] [8] and integration of intelligent analitycal methods [9] [10] [11]. The need for mineral processing of raw materials is increasing day by day and many studies have been done for the development of optimal processing technology [12]. Formerly, there is a high demand for chromite in refractory bricks making and also in chemical industries to manufacture sodium and potassium dichromate [13]. Its formula is $\mathrm{FeCr}_{2} \mathrm{O}_{4}$ or in a more scientific way, it consists of $\mathrm{FeOCr}_{2} \mathrm{O}_{3}$, with a theoretical composition of $68 \% \mathrm{Cr}_{2} \mathrm{O}_{3}$, and $32 \% \mathrm{FeO}$. This mineral, like other minerals, is rarely found in theoretical formula state and has different inclusions and elements which substitute with main elements such as iron which mainly replaced by magnesium, and chromium by aluminum and ferric iron, in other words, natural chromite will have this formula ( $\mathrm{Fe}, \mathrm{Mg}) \mathrm{O}(\mathrm{Cr}, \mathrm{Al}, \mathrm{Fe})_{2} \mathrm{O}_{3}$ [14]. According to the presence of $\mathrm{FeO}$ or $\mathrm{Fe}_{2} \mathrm{O}_{3}$ in the formula of this mineral, chromite is a paramagnetic mineral that makes it feasible to beneficiate this ore with the magnetic separation method [15]. Specific gravity of chromite varies from 4 to 4.8 , depends on grade and inclusions, which makes the gravity separation method the best available technology to enrich chromite and separate it from other gangue minerals such as talc, chlorite, serpentine, olivine, pyroxene, amphibole, albite, chrysotile and augite [16]. The gravity separation method is the oldest separation method which can be applied by different types of equipment, including jigging, shaking table, multi gravity separator, Humphrey spiral, and also numerous obsolete devices in the history [17]. Batty et al. in 1947 produced a concentrate with $43.5 \% \mathrm{Cr}_{2} \mathrm{O}_{3}$ grade at a recovery of $77 \%$ [18], from Fairview chromite deposit with an average composition of $18.1 \% \mathrm{Cr}_{2} \mathrm{O}_{3}$, by jigging which is the most popular method for coarse or lump chromite ores, A. A. Seifelnasr in 2012 successfully used a shaking table to produce a concentrate from Chickay mine, east of Sudan, with $47.2 \% \mathrm{Cr}_{2} \mathrm{O}_{3}$ grade, and $75 \%$ recovery from an ore with average $\mathrm{Cr}_{2} \mathrm{O}_{3}$ composition of 30\% - 35\% [19], Gence in 1999 produced a concentrate with multi gravity separator or MGS, with $52.1 \% \mathrm{Cr}_{2} \mathrm{O}_{3}$ at a recovery of 69.6\% from Elazig-Kefdag chromite ore in Turkey with an average composition of $38.33 \% \mathrm{Cr}_{2} \mathrm{O}_{3}$ [20]. Tevfik in 2007 produced a concentrate by Humphrey spiral with $54.6 \% \mathrm{Cr}_{2} \mathrm{O}_{3}$ and $94.9 \%$ recovery from Topraktepe chromite ore with an average composition of $47.68 \% \mathrm{Cr}_{2} \mathrm{O}_{3}$ [21]. On the other hand, the magnetic separation method which is used for separating magnetic from non-magnetic minerals according to their magnetic susceptibility, is applicable for the chromite beneficiation method [17] [22].

According to the former research works, the recovery of chromite tailings was not studied due to access to high-grade raw materials. But nowadays, with the decreasing amount of economic reserves, secondary mining methods are flourishing gradually, recycling, tailing mining, deep-sea mining, cosmos mining, landfill mining, and other technics are alternatives for usual mining to reach an economic concentrate [23], which among them extracting and recovering metals from mine tailings is more feasible and accessible for mining companies and societies, due to ease of access and the lowest amount of operating costs. Here in 
this study, recovery of chromite from tailings of shaking table unit of the Forumad plant by magnetic methods has been studied to produce a final concentrate to use directly or indirectly in metallurgical final applications. This method had chosen due to ease of operation, low cost, not the use of further reagents, and the minimum amount of environmental impacts.

\section{Location}

Iran is known as an oil land, but there are a variety of minerals in this country [24], chromite is one of them, which can be found almost everywhere in Iran, important known chromite districts of Iran are situated in Sabzevar and Torbate Jam districts in Khorasan Razavi, the northeastern part of Iran, Faryab and Esfandaghe districts in Hormozgan south of Iran, Other occurrences are known Makran districts in Sistan and Balouchestan eastern and southeastern of Iran, Neyriz districts in Fars and Naein in Isfahan, the central part of Iran and Khoy district in West Azerbaijan in the northwestern region of Iran [25] [26]. Most of the deposits are alpine type chromite, which is distributed in several places like schlieren bands, massive lenses, and dissemination in serpentinized ultrabasic rocks [27]. Forumad mine and processing plant is located in Sabzevar district and has an alpine type deposit, with similar minerals and rock compositions (Figure 1).

\section{Material and Method}

$300 \mathrm{~kg}$ of fresh tailing sample obtained from Forumad Plant, was used in the magnetic separation studies, an average grade of $\mathrm{Cr}_{2} \mathrm{O}_{3}$ determined $7.62 \%$ in the tailing depot of shaking table operation by XRF, also different mineral phases had been determined by XRD, which were chrysotile, Augite, Albite, Chlorite, and Chromite. Chemical analysis of a representative sample is summarized in Table 1.

After collecting the sample, it has been classified into two fractions $0-0.5 \mathrm{~mm}$ and $0.5-2 \mathrm{~mm}$ by a wet screen, which chemical analysis of each fraction showed in Table 2. 58.49\% weight percentage of the sample was in $0.5-2 \mathrm{~mm}$ fraction and $41.51 \%$ weight percentage of was in $0-0.5 \mathrm{~mm}$ fraction which wasn't used

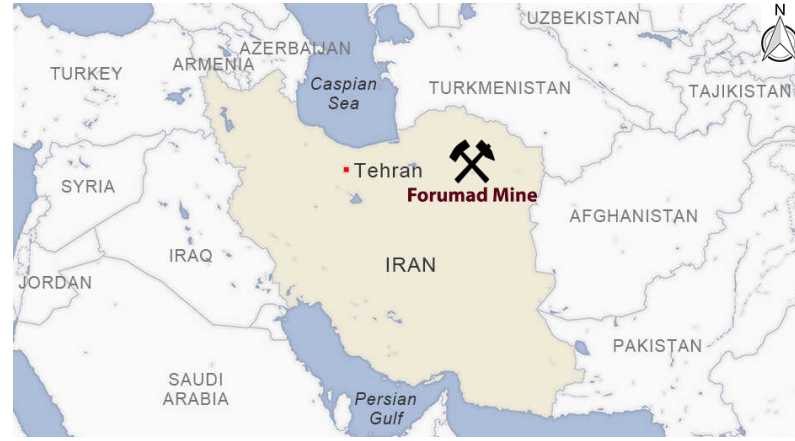

(a)

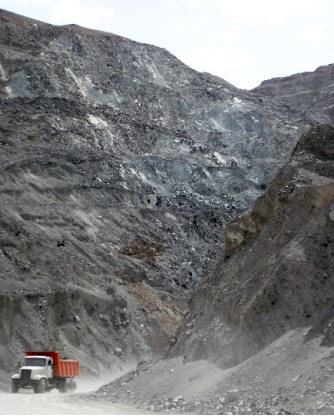

(b)

Figure 1. (a) Location map of Forumad mine; (b) A view of Forumad open pit. 
Table 1. The chemical composition of representative sample.

\begin{tabular}{lccccccccc}
\hline & $\mathrm{Cr}_{2} \mathrm{O}_{3}$ & $\mathrm{MgO}$ & $\mathrm{FeO}$ & $\mathrm{Fe}_{2} \mathrm{O}_{3}$ & $\mathrm{SiO}_{2}$ & $\mathrm{Al}_{2} \mathrm{O}_{3}$ & $\mathrm{~S}$ & $\mathrm{P}$ & L.O.I \\
\hline Percentage (\%) & 7.62 & 30.90 & 2.52 & 4.62 & 31.04 & 2.78 & 0.1 & 0.009 & 22.94 \\
\hline
\end{tabular}

Table 2. The chemical composition of fractions.

\begin{tabular}{cccccccccc}
\hline Size Fraction & $\begin{array}{c}\mathrm{Cr}_{2} \mathrm{O}_{3} \\
(\%)\end{array}$ & $\begin{array}{c}\mathrm{MgO} \\
(\%)\end{array}$ & $\mathrm{FeO}(\%)$ & $\begin{array}{c}\mathrm{Fe}_{2} \mathrm{O}_{3} \\
(\%)\end{array}$ & $\mathrm{SiO}_{2}(\%)$ & $\begin{array}{c}\mathrm{Al}_{2} \mathrm{O}_{3} \\
(\%)\end{array}$ & $\mathrm{S}(\%)$ & $\mathbf{P}(\%)$ & $\begin{array}{c}\text { L.O.I } \\
(\%)\end{array}$ \\
\hline $\mathbf{0 . 5}-\mathbf{2} \mathrm{mm}$ & 7.51 & 33.21 & 2.47 & 4.87 & 35.51 & 2.73 & 0.1 & 0.009 & 13.59 \\
$\mathbf{0}-\mathbf{0 . 5} \mathrm{mm}$ & 7.77 & 27.24 & 2.63 & 4.29 & 24.41 & 4.73 & 0.1 & 0.008 & 28.82 \\
\hline
\end{tabular}

for magnetic tests due to slime behavior of this size fraction. This characteristic has been determined by 3 characterization magnetic tests before designing the tests.

Three different magnetic separators which been used in this study are made by Papco Magnet Company. A usual low-intensity magnetic separator with 2000 gauss or 0.2-tesla magnetic field, a high-intensity magnetic separator with 7000 gauss or 0.7 -tesla magnetic field, and another high-intensity magnetic separator with 10,000 gauss or 1-tesla magnetic field, all these three magnetic separators used permanent magnets in their structure.

27 tests for 3 factors in 3 levels designed by the Taguchi method with design expert 12 software to measure optimum conditions of grade and recovery. Magnetic field intensity, feeding rate, and drum rotating speed were selected as main factors that can determine the performance of magnetic separation [28].

\section{Results and Discussion}

The results of these 27 tests have been shown in Table 3. Test number 15, gave the best result in grade which shows, increase in magnetic field intensity besides decreasing drum speed and feed rate can increase the grade, and make a semi-concentrate from a tailing. Based on these observations, low-intensity magnetic separation cannot help for the beneficiation of chromite as expected. On the other hand, for better industrial results, increasing field magnetic intensity is essential. In fact, magnetic intensity less than 10,000 gauss or 1 tesla is impractical in the beneficiation of chromite.

After measuring The $\mathrm{Cr}_{2} \mathrm{O}_{3}$ content of concentrate, tailings, and the feed by $\mathrm{XRF}$, operation recovery was calculated by the following equation:

$$
R=\frac{C c}{F f} \times 100
$$

\subsection{Operational Effects}

To have a higher quality understanding of data in Table 3, Figures 2-5 are demonstrated the effects of each parameter on grade and recovery. Based on Figure 2, increasing the intensity of the magnetic field can increase the grade of 
Table 3. Results of tests.

\begin{tabular}{|c|c|c|c|c|c|}
\hline Test Run No. & $\begin{array}{c}\text { Magnetic Field } \\
(\mathrm{T})\end{array}$ & $\begin{array}{l}\text { Drum Speed } \\
\quad(\mathrm{rpm})\end{array}$ & $\begin{array}{c}\text { Feed Rate } \\
(\mathrm{Kg} / \mathrm{min})\end{array}$ & $\begin{array}{c}\text { Recovery Rate } \\
(\%)\end{array}$ & Grade (\%) \\
\hline 1 & 1 & 80 & 2 & 76.19 & 19.28 \\
\hline 2 & 0.7 & 60 & 2 & 71.48 & 11.28 \\
\hline 3 & 0.2 & 80 & 1 & 6.36 & 4.62 \\
\hline 4 & 0.7 & 40 & 1 & 55.56 & 15.89 \\
\hline 5 & 1 & 60 & 2 & 74.58 & 22.49 \\
\hline 6 & 0.7 & 40 & 2 & 61.24 & 12.54 \\
\hline 7 & 0.2 & 40 & 4 & 3.47 & 6.15 \\
\hline 8 & 0.7 & 60 & 4 & 75.46 & 9.48 \\
\hline 9 & 0.2 & 80 & 4 & 12.51 & 6.25 \\
\hline 10 & 0.7 & 80 & 1 & 73.52 & 11.86 \\
\hline 11 & 1 & 40 & 4 & 72.15 & 24.85 \\
\hline 12 & 1 & 60 & 1 & 62.41 & 31.26 \\
\hline 13 & 0.2 & 60 & 2 & 6.29 & 4.46 \\
\hline 14 & 0.7 & 80 & 2 & 78.49 & 9.89 \\
\hline 15 & 1 & 40 & 1 & 59.42 & 34.65 \\
\hline 16 & 0.2 & 60 & 1 & 5.26 & 3.89 \\
\hline 17 & 1 & 40 & 2 & 67.21 & 29.86 \\
\hline 18 & 0.2 & 40 & 2 & 5.51 & 4.56 \\
\hline 19 & 1 & 80 & 4 & 81.49 & 16.21 \\
\hline 20 & 1 & 80 & 1 & 64.61 & 27.59 \\
\hline 21 & 0.2 & 60 & 4 & 6.57 & 5.81 \\
\hline 22 & 0.7 & 40 & 4 & 64.79 & 11.46 \\
\hline 23 & 1 & 60 & 4 & 78.85 & 18.86 \\
\hline 24 & 0.7 & 80 & 4 & 82.59 & 8.49 \\
\hline 25 & 0.7 & 60 & 1 & 69.49 & 12.56 \\
\hline 26 & 0.2 & 40 & 1 & 2.87 & 2.62 \\
\hline 27 & 0.2 & 80 & 2 & 6.54 & 5.91 \\
\hline
\end{tabular}
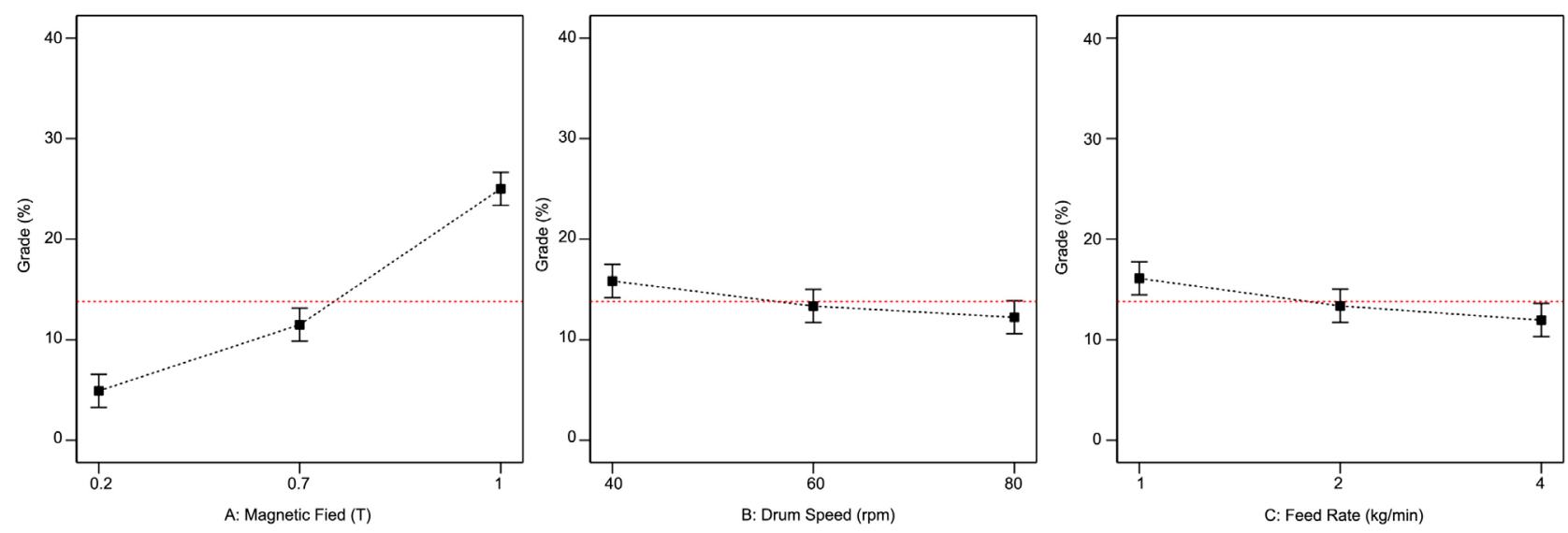

Figure 2. One factor diagrams of grade. 

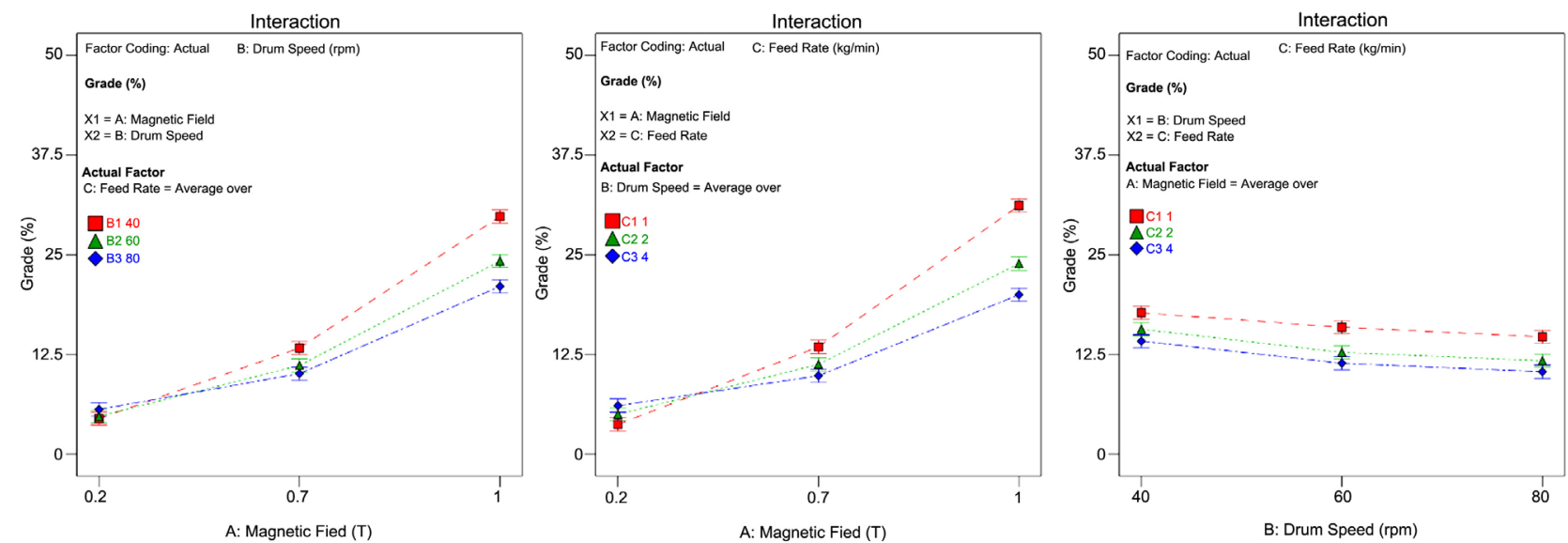

Figure 3. Factors Interaction diagrams of grade.
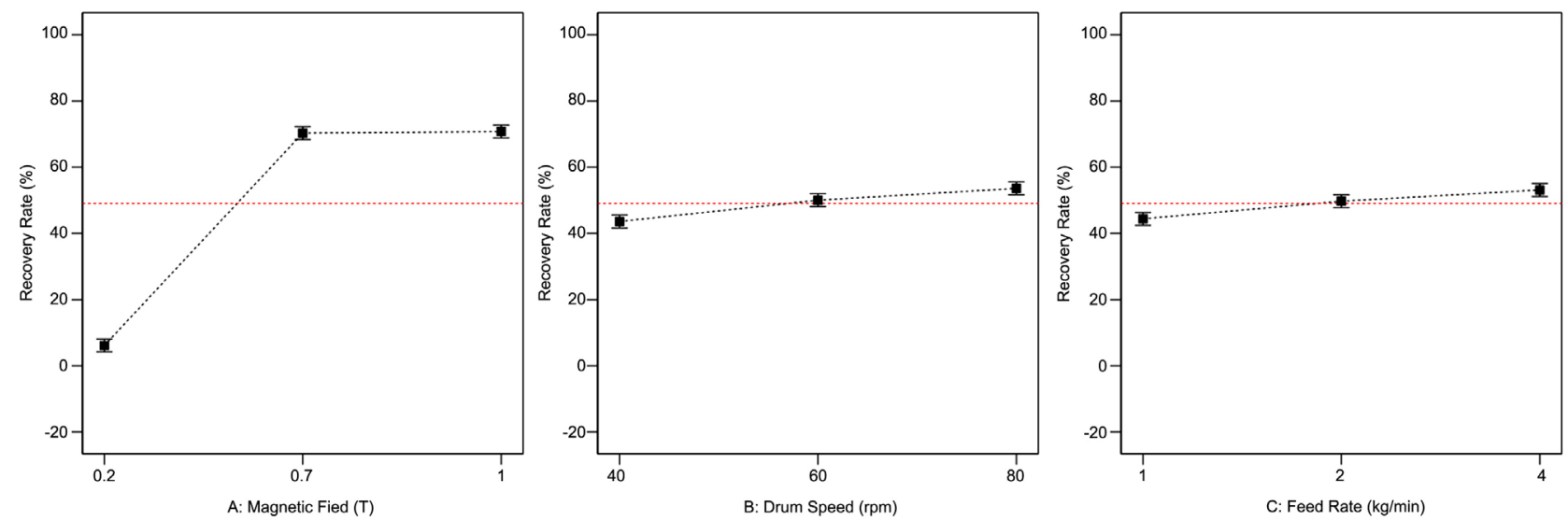

Figure 4. One factor diagrams of recovery.
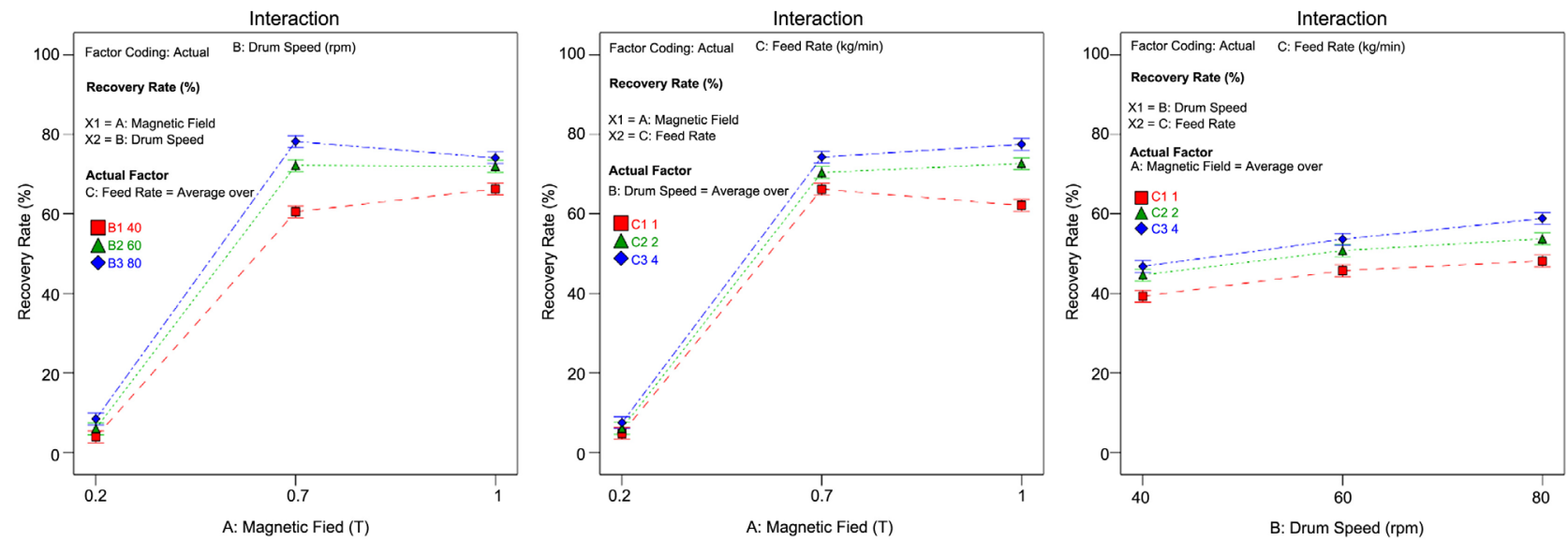

Figure 5. Factors interaction diagrams of recovery.

attracted materials in concentrate as expected [15] [29], paramagnetic materials will attract more to a stronger magnetic field, but there is one more important point, which different magnetic field intensities, show different behavior on materials, in some cases increasing in magnetic field intensity will decrease both grade and recovery due to presence of middlings which this phenomena roots to 
poorly liberation of feed. Also, increasing drum speed is decreasing grades again as expected [30] because it will decrease the accuracy of separation, and have a negative effect on separation efficiency. The reason for this phenomenon is with the increasing speed of the pulley, the impact time of magnetic attraction will decrease and as a result, these forces won't acting properly and accurately. Increasing feed rate will cause a decreasing grade of chromite concentrate which attracted by the magnetic field, one of the reasons for this phenomena is the formation of several layers of chromite on each other which decrease the magnetic effect of separator apply to these paramagnetic particles, so the separation operation will be incomplete. Besides that, separation efficiency will decrease subsequently due to a drop in magnetic susceptibility.

In Figure 3, diagrams of 2 factors interactions for grade has been shown for all factors separately. As can be seen in the diagram of magnetic field interaction with drum rotating speed, the best result of the grade will come after an increase of magnetic field and decrease of drum speed and feed rate, together. Furthermore, as it can be seen in the magnetic field/feed rate interaction diagram, another time, the higher grade will be the result of an increase in the magnetic field and decrease of feed rate. And, on the other hand, the drum speed/feed rate interaction diagram, shows increasing both factors together will decrease grade regarding the aforementioned reasons.

In Figure 4 and Figure 5, one-factor diagrams of recovery and Factors Interaction diagrams of recovery have been shown, respectively. As can be seen from both figures increase of the magnetic field will increase the recovery rate of chromite from tailings to the concentrate, moreover increase of drum speed and feed rate will cause a decrease in recovery, however, the effect of drum speed change in toleration of recovery is negligible. All these results confirm the principles of magnetic separation parameters on paramagnetic minerals [28]. Finally, after 27 tests for 3 factors in 3 levels, the optimum condition was obtained with 10,000 gauss or 1 tesla in magnetic field intensity, 1 kilogram per minute feeding rate, and $40 \mathrm{rpm}$ drum rotating speed which produced a concentrate with $34.65 \% \mathrm{Cr}_{2} \mathrm{O}_{3}$ and $59.42 \%$ recovery.

\subsection{Mineralogical Effects}

Based on Haggerty studies [14], the formula of Chromite can vary in this form $(\mathrm{Fe}, \mathrm{Mg}) \mathrm{O}(\mathrm{Cr}, \mathrm{Al}, \mathrm{Fe})_{2} \mathrm{O}_{3}$, where magnetic susceptibility of the mineral has a direct relation to its elemental composition [31] [32] [33] [34]. As a result of this fact, chromites with more Iron content in its crystal structure will have more magnetic susceptibility, and this can result in more attraction by magnetic fields of magnetic separators and consequently better separation efficiency of chromite particles from gangue particles.

\subsection{Conditions of Semi-Industrial Tests}

Regarding test results, the only feasible magnetic separators are high-intensity 
ones with more or equal to 1 tesla or 10,000 gauss, magnetic field intensity. Due to this fact, test results of 10,000 gauss magnetic field intensity, modeled separately by design expert 12 software to obtain, better perception of parameters in the industrial environment.

According to the diagrams which have been shown in Figure 6, increasing drum speed and feed rate cause grade reduction of concentrates. However, this increase has a reverse effect on the recovery rate of chromite fragments of the tailing. These outcomes show the effect of magnetic momentum on separation efficiency and behavior of paramagnetic material in the magnetic field. Reduction in magnetic susceptibility in different forms of mineralogical and operational will result in grade drop.
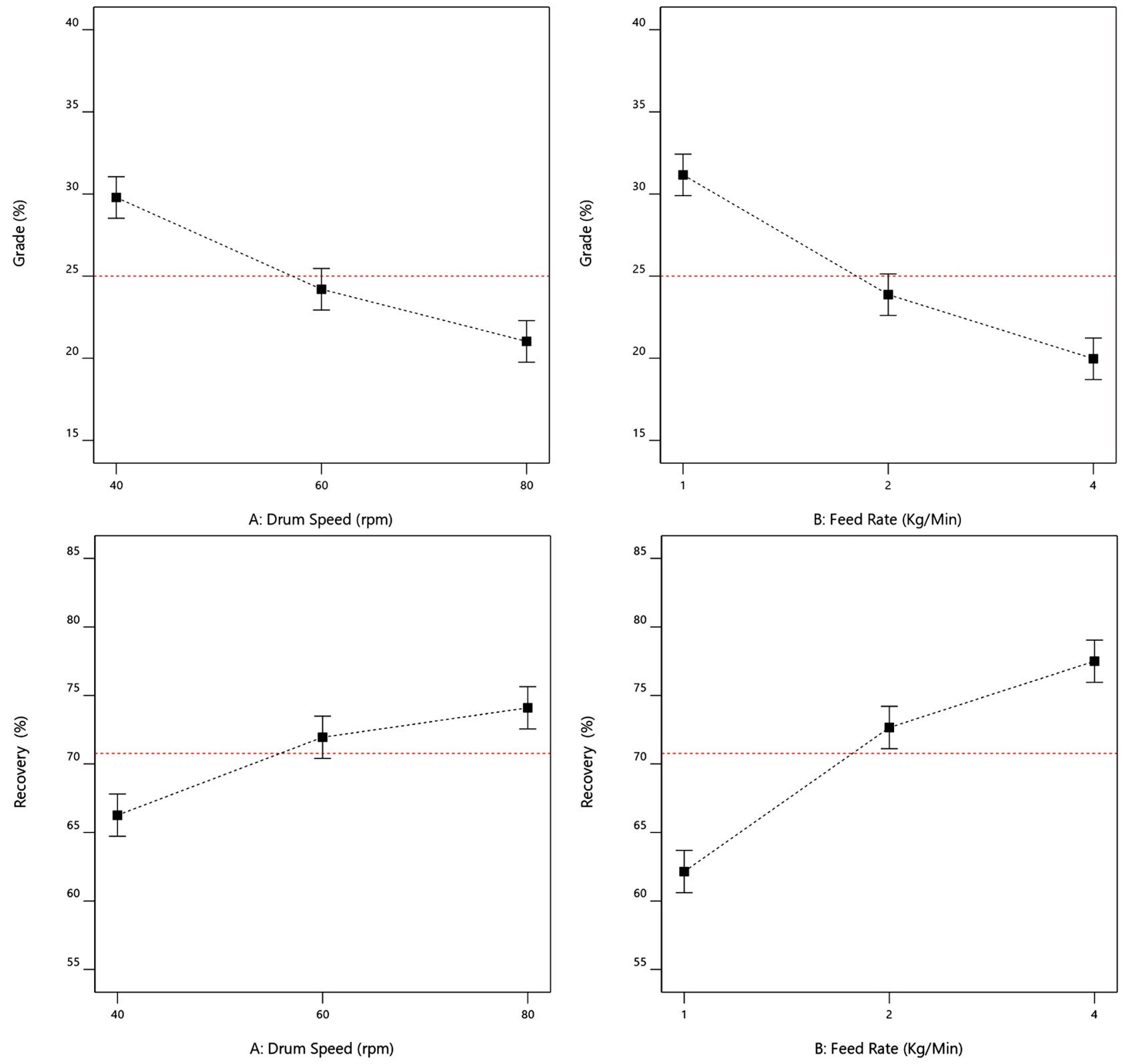

Figure 6. Grade and recovery diagrams for 1 tesla tests. 


\section{Conclusions}

Day to day, economic reserves of minerals reaching the end, due to this fact more alternatives need to be found to fill the supply void space. For chromite and other metallic minerals which are strategic to the global economy and industry, there are several methods to reach this aim, including recycling of scrap metals, landfill mining, deep-sea mining, and recovery of minerals from tailing depots and old tailing dams, which among them recycling scrap metals and recovery of tailings are more feasible and environmentally friendly.

According to the results of this study, the magnetic separation can be a reliable method to produce a concentrate which can be used as a raw material of gravity separation methods of run of mine, also it can be blended with high grade concentrates to increase recovery of the whole flow-sheet. On the other hand, experiments showed which low-intensity magnetic separators are not useful neither for this method nor for other methods which rejecting magnetite from ore to increase $\mathrm{Cr} / \mathrm{Fe}$ ratio, because a portion of this strategic mineral will be removed by this method, and this result is due to low magnetic susceptibility of chromite. Also, the elemental composition of minerals affects directly separation efficiency. All in all, the recovery of alpine chromites from old tailings seems feasible and economic by the magnetic method.

\section{Conflicts of Interest}

The authors declare no conflicts of interest regarding the publication of this paper.

\section{References}

[1] Murthy, Y.R., Tripathy, S.K. and Kumar, C.R. (2011) Chrome Ore Beneficiation Challenges \& Opportunities-A Review. Minerals Engineering, 24, 375-380. https://doi.org/10.1016/j.mineng.2010.12.001

[2] Shirazi, A., Shirazy, A. and Karami, J. (2018) Remote Sensing to Identify Copper Alterations and Promising Regions, Sarbishe, South Khorasan, Iran. International Journal of Geology and Earth Sciences, 4, 36-52.

[3] Shirazi, A., et al. (2018) Remote Sensing Studies for Mapping of Iron Oxide Regions, South of Kerman, Iran. International Journal of Science and Engineering Applications, 7, 45-51. https://doi.org/10.7753/IJSEA0704.1002

[4] Alahgholi, S., Shirazy, A. and Shirazi, A. (2018) Geostatistical Studies and Anomalous Elements Detection, Bardaskan Area, Iran. Open Journal of Geology, 8, 697-710. https://doi.org/10.4236/ojg.2018.87041

[5] Shirazi, A., et al. (2018) Geostatistics Studies and Geochemical Modeling Based on Core Data, Sheytoor Iron Deposit, Iran. Journal of Geological Resource and Engineering, 6, 124-133. https://doi.org/10.17265/2328-2193/2018.03.004

[6] Shirazi, A., et al. (2018) Exploration Geochemistry Data-Application for Cu Anomaly Separation Based On Classical and Modern Statistical Methods in South Khorasan, Iran. International Journal of Science and Engineering Applications, 7, 39-44. https://doi.org/10.7753/IJSEA0704.1001

[7] Shirazy, A., Ziaii, M. and Hezarkhani, A. (2020) Geochemical Behavior Investiga- 
tion Based on K-Means and Artificial Neural Network Prediction for Copper, in Kivi Region, Ardabil Province, Iran.

[8] Shirazi, A. and Hezarkhani, A. (2018) Predicting Gold Grade in Tarq 1:100000 Geochemical Map Using the Behavior of Gold, Arsenic and Antimony by K-Means Method.

[9] Shirazi, A., et al. (2018) Introducing a Software for Innovative Neuro-Fuzzy Clustering Method Named NFCMR. Global Journal of Computer Sciences. Theory and Research, 8, 62-69. https://doi.org/10.18844/gjcs.v8i2.3264

[10] Shirazy, A., et al. (2019) Geochemical and Geostatistical Studies for Estimating Gold Grade in Tarq Prospect Area by K-Means Clustering Method. Open Journal of Geology, 9, 306-326. https://doi.org/10.4236/ojg.2019.96021

[11] Shirazy, A., et al. (2020) Geostatistical and Remote Sensing Studies to Identify High Metallogenic Potential Regions in the Kivi Area of Iran. Minerals, 10, 869. https://doi.org/10.3390/min10100869

[12] Khakmardan, S., et al. (2018) Copper Oxide Ore Leaching Ability and Cementation Behavior, Mesgaran Deposit in IRAN. Open Journal of Geology, 8, 841.

https://doi.org/10.4236/ojg.2018.89049

[13] Nafziger, R.H. (1982) A Review of the Deposits and Beneficiation of Lower-Grade Chromite. Journal of the Southern African Institute of Mining and Metallurgy, 82, 205-226.

[14] Haggerty, S.E. (1991) Oxide Mineralogy of the Upper Mantle. In: Lindsley, D.H., Ed., Oxide Minerals: Petrologic and Magnetic Significance, De Gruyter, Berlin, 355-416. https://doi.org/10.1515/9781501508684-013

[15] Bhatti, M.A., Kazmi, K.R. and Anwar, M.S. (2008) High Intensity Magnetic Separation Studies of Low Grade Chromium Ore. Journal-Chemical Society of Pakistan, 30,42 .

[16] Zhou, M.-F., et al. (2014) Compositions of Chromite, Associated Minerals, and Parental Magmas of Podiform Chromite Deposits: The Role of Slab Contamination of Asthenospheric Melts in Suprasubduction Zone Environments. Gondwana Research, 26, 262-283. https://doi.org/10.1016/j.gr.2013.12.011

[17] Wills, B.A. and Napier-Munn, T. (2006) Wills' Mineral Processing Technology: An Introduction to the Practical Aspects of Ore Treatment and Mineral Recovery. Elsevier Science and Technology, Amsterdam. https://doi.org/10.1016/B978-075064450-1/50003-5

[18] Batty, J.V. (1947) Beneficiation of Chromite Ores from Western United States. Department of the Interior, Bureau of Mines, USA.

[19] Seifelnasr, A.A., Tammam, T. and Abouzeid, A.-Z.M. (2012) Gravity Concentration of Sudanese Chromite Ore Using Laboratory Shaking Table. Physicochemical Problems of Mineral Processing, 48, 271-280.

[20] Gence, N. (1999) Beneficiation of Elazig-Kefdag Chromite by Multi Gravity Separator.

[21] Tevfik, A.Z. and Aydogan, S. (2007) Beneficiation of Low-Grade Chromite of Abandoned Mine at Topraktepe. Acta Montanistica Slovaca Rocnik, 12, 323-327.

[22] Starun, V., et al. (1960) Concentration of Chromite from the Kempersayi Deposit by Magnetic Separation. Refractories, 1, 86-91. https://doi.org/10.1007/BF01283721

[23] Falagán, C., Grail, B.M. and Johnson, D.B. (2017) New Approaches for Extracting and Recovering Metals from Mine Tailings. Minerals Engineering, 106, 71-78. https://doi.org/10.1016/j.mineng.2016.10.008 
[24] Shirazi, A. and Shirazy, A. (2020) Introducing Geotourism Attractions in Toroud Village, Semnan Province, Iran.

[25] Yaghoubpour, A. and Hassannejad, A. (2006) The Spatial Distribution of Some Chromite Deposits in Iran, Using Fry Analysis.

[26] Malekghasemi, F. and Somarin, A.K. (2005) Petrology and Origin of Chromite Mineralisation in the Khoy Area, NW Iran. BHM Berg-und Hüttenmännische Monatshefte, 150, 358. https://doi.org/10.1007/BF03166826

[27] Soleimani, M. and Shokri, B.J. (2016) Intrinsic Geological Model Generation for Chromite Pods in the Sabzevar Ophiolite Complex, NE Iran. Ore Geology Reviews, 78, 138-150. https://doi.org/10.1016/j.oregeorev.2016.03.013

[28] Rezai, B. (1999) Mineral Processing Technology (Beneficiation with Magnetic Methods). Amirkabir University of Technology Publication, Tehran.

[29] Aslan, N. and Kaya, H. (2009) Beneficiation of Chromite Concentration Waste by Multi-Gravity Separator and High-Intensity Induced-Roll Magnetic Separator. Arabian Journal for Science and Engineering, 34, 285.

[30] Rezai, B. (1998) Mineral Processing Technology (Beneficiation with Gravity Methods). Hormozgan University Publication, Minab.

[31] Dahlin, D.C. and Rule, A.R. (1993) Magnetic Susceptibility of Minerals in High Magnetic Fields. Vol. 9449, US Department of the Interior, Bureau of Mines, Washington DC.

[32] Rais, A., et al. (1997) Magnetic Susceptibilities of Chromites from Oman. Mineralogical Magazine, 61, 726-728. https://doi.org/10.1180/minmag.1997.061.408.14

[33] Fajri, R.N., et al. (2020) Analyzing Magnetic Susceptibility and Elemental Composition of Rocks and Soil around Danau Diatas, West Sumatra, Indonesia. Journal of Physics: Conference Series, 1481, Article ID: 012022. https://doi.org/10.1088/1742-6596/1481/1/012022

[34] Li, Y., et al. (2014) The Relationships between Magnetic Susceptibility and Elemental Variations for Mineralized Rocks. Journal of Geochemical Exploration, 146, 17-26. https://doi.org/10.1016/j.gexplo.2014.07.010 